\title{
Pengaruh Ukuran Kantor Akuntan Publik (KAP), Ukuran Perusahaan Dan Opini Audit terhadap Auditor Switching
}

\section{The Effect Of Audit Firm Size, Firm Size And Audit Opinion To Auditor Switching}

\author{
Ridho Wardana ${ }^{1}$, Auliffi Ermian Challen ${ }^{1}$ \\ Program Studi Akuntansi, Fakultas Ekonomi Universitas YARSI, Jakarta \\ E-mail: Korenponden: auliffi.ermian@yarsi.ac.id
}

KEYWORDS Audit Firm Size, Firm Size, Audit Opinion, Auditor Switching

ABSTRACT The aim of this study is to examine the influence of Audit Firm Size, Firm Size, and Audit Opinion towards Auditor Switching. Some of past research regarding auditor switching, shows different results. Because of that, another research needs to be done to verify theory of auditor switching. The purpose of this research is to find empirical proof concerning factors that might influence auditor switching in Indonesia.This research used the sample of real estate and property industries which listed in Indonesian Stock Exchange during 2010-2014 periods. The number of real estate and property industries sampled in this study were 10 companies with 5 years observation. Based on purposive sampling method, sample consist of 50 financial statements in this research. Research variable being used are Audit Firm Size (KAP), Firm Size (LnTA), Audit Opinion (OPINI), and Auditor Switching (SWITCH). By using logistic regression in SPSS 20 software. The result of this research shown below: (1) Audit Firm Size has effect on Auditor Switching, (2) Firm Size does not has effect towards Auditor Switching, and (3) Audit Opinion does not has effect towards Auditor Switching.

\section{PENDAHULUAN}

Laporan keuangan pada dasarnya adalah hasil dari proses akuntansi yang dapat digunakan sebagai alat untuk menghubungkan antara data keuangan atau aktivitas suatu perusahaan dengan pihak-pihak yang berkepentingan dengan data atau aktivitas perusahaan tersebut. Laporan keuangan dibuat oleh pihak perusahaan yang bertujuan untuk mengetahui kondisi keuangan perusahaan dalam satu periode. Setelah laporan keuangan selesai dibuat, perusahaan melakukan RUPS (Rapat Umum Pemegang Saham) yang dihadiri oleh para pemegang saham dan juga pihak perusahaan untuk memutuskan apakah laba perusahaan akan dibagikan sebagai dividen atau diberikan kepada pihak perusahaan menjadi laba ditahan untuk tambahan modal perusahaan.

Namun sebelum laporan keuangan diberikan kepada pemegang saham, pihak perusahaan terlebih dahulu harus melakukan pemeriksaan laporan 
keuangan. Pemeriksaan laporan keuangan harus di periksa oleh akuntan publik yang bertujuan mendapatkan opini dari auditor. Sukrisno (2012, 73) menjelaskan pengertian dari audit keuangan adalah suatu pemeriksaan yang dilakukan secara kritis dan sistematis oleh pihak independen, terhadap laporan keuangan yang telah disusun oleh manajemen beserta catatan pembukuan dan buktibukti pendukungnya, dengan tujuan untuk dapat memberikan pendapat mengenai kewajaran laporan keuangan yang terdapat lima jenis opini audit.

Apabila perusahaan hanya menggunakan internal audit dari perusahaan, bisa terjadi manipulasi data, maka dari itu diwajibkan setiap perusahaan diharuskan untuk laporan keuangannya di audit oleh auditor eksternal dari kantor akuntan publik. Hal tersebut dilakukan agar tidak terjadi adanya kecurangan dan manipulasi data. Akuntan publik merupakan pihak independen yang dianggap mampu menjembatani benturan kepentingan antara pihak pemegang saham dengan pengelola perusahaan. Dalam hal ini peran akuntan publik adalah memberi opini terhadap kewajaran laporan keuangan yang disajikan perusahaan. Untuk dapat menjalankan fungsi dan tugasnya dengan baik, auditor harus mampu menghasilkan opini audit yang berkualitas yang akan berguna tidak saja bagi dunia bisnis, tetapi juga masyarakat luas (Wibowo dan Rossieta, 2009, 6).

Menurut Susan dan Trisnawati (2011, 3) setiap perusahaan yang go public diwajibkan untuk menyampaikan laporan keuangan yang disusun sesuai dengan Standar Akuntansi Keuangan (SAK) dan telah diaudit oleh akuntan publik yang terdaftar di Badan Pengawasan Pasar Modal (BAPEPAM). Hal ini sangat berpengaruh terhadap perkembangan profesi Kantor Akuntan Publik (KAP) yang ada di Indonesia. Kantor Akuntan Publik (KAP) yang tercatat di BAPEPAM sebanyak 203 KAP. Banyaknya KAP yang beroperasi memberikan pilihan kepada perusahaan untuk tetap menggunakan KAP yang sama atau melakukan pergantian KAP (auditor switching). Oleh karena itu terjadi persaingan antara kantor akuntan publik untuk mendapatkan klien (perusahaan) dengan cara berusaha memberikan jasa audit sebaik mungkin.

Masalah penyimpangan yang dilakukan oleh akuntan publik sering terjadi di berbagai negara. Amerika Serikat yang selama ini dianggap sebagai negara super power dan juga kiblat ilmu pengetahuan termasuk disiplin ilmu akuntansi harus menelan kepahitan. Skandal bisnis yang terjadi seakan menghilangkan kepercayaan oleh para pelaku bisnis dunia. Seperti Enron yang hancur begitu saja karena melakukan kecurangan dalam bentuk merekayasa laporan keuangan bisnis yang menimpa perusahaan-perusahaan besar di Amerika Serikat.

Di Indonesia, kasus kecurangan akuntansi terjadi pada PT Kimia Farma. PT Kimia Farma melakukan penggelembungan persediaan dan diduga KAP yang bersangkutan terlibat dalam kasus tersebut. Mantan direksi PT Kimia Farma Tbk telah terbukti melakukan pelanggaran dalam kasus dugaan penggelembungan (mark up) laba bersih di laporan keuangan Badan Usaha Milik Negara (BUMN) untuk tahun buku 2001. Kementerian BUMN dan BAPEPAM menilai bahwa laba bersih tersebut terlalu besar dan mengandung unsur rekayasa. Setelah dilakukan audit ulang, pada 3 Oktober 2002 laporan keuangan PT Kimia Farma 2001 disajikan kembali (restated), karena telah ditemukan 
kesalahan yang cukup mendasar. Pada laporan keuangan yang baru, keuntungan yang disajikan hanya sebesar Rp 99,56 miliyar, atau lebih rendah sebesar $\mathrm{Rp}$ 32,6 miliyar, atau $24,7 \%$ dari laba awal yang dilaporkan. Berdasarkan penyelidikan BAPEPAM, disebutkan bahwa KAP yang mengaudit laporan keuangan PT Kimia Farma telah mengikuti standar audit yang berlaku, namun gagal mendeteksi kecurangan tersebut. Selain itu, KAP tersebut juga tidak terbukti membantu manajemen melakukan kecurangan tersebut (Kompasiana, 2015).

Menurut Febrianto (2009, 10) pergantian auditor bisa terjadi secara voluntary (sukarela) atau secara mandatory (wajib). Jika pergantian auditor terjadi secara voluntary, maka faktor-faktor penyebab dapat berasal dari sisi klien (misalnya kesulitan keuangan, manajemen yang gagal, perubahan ownership, initial public offering, dan sebagainya) dan dari sisi auditor, misalnya fee audit, kualitas audit, dan sebagainya. Sebaliknya, jika pergantian terjadi secara mandatory, berarti hal itu terjadi karena adanya peraturan yang mewajibkan. Oleh sebab itu Fenomena mengenai pergantian auditor atau Kantor Akuntan Publik (KAP) memang sangat menarik untuk dikaji. Ukuran KAP mempengaruhi kualitas audit yang berdampak pada terjadinya pergantian auditor (Wijaya, 2011, 17). Ukuran dari KAP digolongkan dalam KAP big-4 dan KAP non big-4. KAP big-4 dianggap lebih mampu meningkatkan indepedensi dibandingkan KAP non big-4 (Aprilia, 2013, 13). Klien cenderung berpindah KAP ke KAP big-4 untuk mendapatkan reputasi perusahaan yang lebih baik lagi. Karena KAP big-4 tidak diragukan keakuratan dalam mengaudit laporan keuangan perusahaan dan juga dalam memberikan opini audit yang sesuai dengan apa yang ada dalam laporan keuangan perusahaan tersebut. KAP big4 sudah diakui tidak hanya di Indonesia, namun juga di dunia (Aprilia, 2013, 13). Dari tindakan seperti itu, maka calon pemegang saham akan berminat untuk menanamkan saham pada perusahaan tersebut. Karena calon pemegang saham melihat apakah laporan keuangan perusahaan tersebut sehat atau tidak (Wijaya, 2011, 17).

Susan dan Trisnawati $(2011,9)$ melakukan pengujian terhadap pengaruh variabel ukuran KAP dan sudah menemukan bukti empiris bahwa ukuran KAP merupakan variabel yang berpengaruh signifikan terhadap auditor switching. Sedangkan Pratini dan Astika $(2013,8)$ membuktikan bahwa ukuran KAP tidak berpengaruh terhadap auditor switching. Menurut Juliantari dan Rasmini (2013, 13) ukuran perusahaan berpengaruh terhadap pergantian kantor akuntan publik. Perusahaan yang lebih besar biasanya lebih kompleks dari pada perusahaan yang lebih kecil. Seiring dengan peningkatan ukuran perusahaan, jumlah hubungan pengelola perusahaan meningkat, dan membuat pemegang saham semakin sulit dan kompleks untuk memonitor tindakan pengelola perusahaan. Menurut Aprilia (2013, 13) keadaan ini secara potensial memicu pergantian ke KAP yang lebih independen.

Ukuran perusahaan klien yang besar memiliki operasional bisnis yang kompleks. Ukuran perusahaan ini akan membawa dampak pada pemilihan Kantor Akuntan Publik (KAP) yang dikaitkan dengan ukuran perusahaan dan jenis layanan yang diperlukan. Ukuran perusahaan yang lebih kecil cenderung untuk melakukan pergantian KAP dengan melakukan perpindahan dari KAP big-4 
ke KAP non big-4 dengan harapan untuk mengurangi biaya manajemen. Penelitian yang dilakukan oleh Wijayanti $(2010,9)$ menemukan bahwa ukuran perusahaan berpengaruh secara signifikan terhadap pergantian KAP yang dilakukan oleh sebuah perusahaan.

Opini audit sering digunakan sebagai alasan oleh manajemen untuk mengganti KAP. Kondisi ini muncul pada saat perusahaan klien tidak setuju dengan opini audit sebelumnya. Secara umum, perusahaan tentunya menginginkan laporan keuangannya mendapat opini wajar tanpa pengecualian dari auditornya. Wijaya $(2011,17)$ telah melakukan penelitian yang berhasil membuktikan adanya pengaruh opini audit tehadap auditor switching. Sedangkan penelitian yang dilakukan Pratini dan Astika $(2013$, 9) menemukan bahwa opini auditor tidak mempengaruhi auditor switching.

Berdasarkan penelitian terdahulu terdapat beberapa research gap. Perbedaaan hasil dari penelitian terdahulu atau terdapat research gap sehingga penelitian bertujuan mengadakan penelitian dengan variabel yang sama berupa ukuran kantor akuntan publik (KAP), ukuran perusahaan dan opini audit untuk membuktikan gap yang muncul. Peneliti juga mengambil sampel penelitian ini pada perusahaan real estate dan properti yang terdaftar di Bursa Efek Indonesia (BEI) periode 2010-2014. Penelitian ini bertujuan untuk mengetahui pengaruh ukuran kantor akuntan publik
(KAP), ukuran perusahaan dan opini audit terhadap auditor switching.

\section{METODOLOGI}

Peneliti menggunakan desain penelitian asosiatif kausal untuk menganalisis bagaimana suatu variabel mempengaruhi variabel lain, dan melihat dampaknya pada variabel dependen secara langsung. Dalam penelitian ini akan menjelaskan bagaimana pengaruh variabel-variabel terhadap auditor switching. Kemudian dengan berdasarkan analisa yang akan dilakukan maka akan ditentukan apakah variabel-variabel tersebut berpengaruh. Metode yang digunakan dalam penelitian ini adalah metode kuantitatif.

Metode penentuan sampel dalam penelitian ini termasuk dalam purposive sampling karena terlebih dahulu sudah ditentukan kriteria-kriteria sampel yang akan diambil. Populasi dalam penelitian ini adalah perusahaan real estate dan properti yang terdaftar di Bursa Efek Indonesia (BEI) periode 2010-2014 sebanyak 49 perusahaan. Penentuan populasi selama lima tahun ini berdasarkan Peraturan Menteri Keuangan tentang auditor swiching yang mengatur pemberian jasa audit oleh KAP paling lama selama 6 tahun berturut-turut. Purposive sampling adalah teknik mengambil sampel dengan menyesuaikan diri berdasar kriteria atau tujuan tertentu (disengaja). Operasionalisasi variabel yang dipakai dalam penelitian ini dapat dilihat pada Tabel 1. 
Tabel 1. Operasionalisasi Variabel

\begin{tabular}{|c|c|c|c|}
\hline Variabel & Konsep Variabel & Indikator & Pengukuran \\
\hline $\begin{array}{l}\text { Auditor } \\
\text { Switching } \\
\text { (Y) }\end{array}$ & $\begin{array}{l}\text { Auditor Switching bisa dibedakan } \\
\text { menjadi } 2 \text { jenis, yaitu pergantian yang } \\
\text { bersifat peraturan (mandatory) dan } \\
\text { pergantian yang bersifat sukarela } \\
\text { (voluntary) (Sinarwati, 2010) }\end{array}$ & $\begin{array}{l}\text { Variabel dummy, nilai } 1 \\
\text { diberikan jika perusahaan } \\
\text { mengganti KAP, dan } 0 \text { untuk } \\
\text { perusahaan yang tidak } \\
\text { mengganti KAP }\end{array}$ & Nominal \\
\hline $\begin{array}{l}\text { Ukuran } \\
\text { KAP (X1) }\end{array}$ & $\begin{array}{l}\text { Ukuran KAP mempengaruhi kualitas } \\
\text { audit. KAP big-4 dianggap lebih } \\
\text { mampu meningkatkan independensi } \\
\text { dibandingkan KAP non big-4 dianggap } \\
\text { memiliki tingkat independensi lebih } \\
\text { rendah dari pada KAP big-4 (Pratini } \\
\text { dan Astika, 2013) }\end{array}$ & $\begin{array}{l}\text { Variabel dummy, nilai } 1 \\
\text { diberikan jika perusahaan } \\
\text { menggunakan KAP big- } 4 \text {, } \\
\text { dan } 0 \text { untuk perusahaan yang } \\
\text { menggunakan KAP selain } \\
\text { KAP big-4 }\end{array}$ & Nominal \\
\hline $\begin{array}{l}\text { Ukuran } \\
\text { Perusahaan } \\
\text { (X2) }\end{array}$ & $\begin{array}{l}\text { Ukuran perusahaan adalah } \\
\text { pengelompokan perusahaan kedalam } \\
\text { beberapa kelompok, diantaranya } \\
\text { perusahaan besar, menengah dan kecil. } \\
\text { Skala perusahaan merupakan ukuran } \\
\text { yang dipakai untuk mencerminkan } \\
\text { besar kecilnya perusahaan yang } \\
\text { didasarkan kepada total aset perusahaan } \\
\text { (Suwito dan Herawaty, 2005). }\end{array}$ & $\begin{array}{l}\text { Logaritma natural dari total } \\
\text { aset }\end{array}$ & Rasio \\
\hline $\begin{array}{l}\text { Opini Audit } \\
\text { (X3) }\end{array}$ & $\begin{array}{l}\text { Opini audit merupakan laporan auditor } \\
\text { untuk memberikan kepastian atas } \\
\text { laporan keuangan perusahaan dan tahap } \\
\text { akhir dari keseluruhan proses audit } \\
\text { (Arens, 2008) }\end{array}$ & $\begin{array}{l}\text { Variabel dummy, nilai } 1 \\
\text { diberikan jika perusahaan } \\
\text { menerima opini selain wajar } \\
\text { Tanpa pengecualian, dan } 0 \\
\text { Untuk perusahaan yang } \\
\text { menerima opini wajar tanpa } \\
\text { pengecualian }\end{array}$ & Nominal \\
\hline
\end{tabular}

Alat analisis data dalam penelitian ini adalah analisis regresi logistik. Alasan penggunaan alat analisis regresi logistik (logistic regression) adalah karena variabel terikatnya yaitu auditor switching merupakan data kuantitatif yang menggunakan variabel dummy dan variabel bebasnya merupakan kombinasi antara variabel matrix dan non-matrix (Sumodiningrat, 2007, 334). Menurut Ghozali $(2011,333)$ penggunaan metode regresi tidak memerlukan asumsi normalitas pada variabel bebasnya. Artinya, variabel penjelasnya tidak harus memiliki distribusi normal, linear, maupun memiliki varian yang sama dalam setiap kelompok. Pengujian hipotesis penelitian menggunakan uji wald. Uji Wald digunakan untuk menguji parameter $\beta \mathrm{i}$ secara parsial pengaruh masing-masing variabel independen $(\mathrm{x})$ terhadap variabel dependennya (y). Model regresi dalam penelitian ini dapat dirumuskan sebagai berkut: 


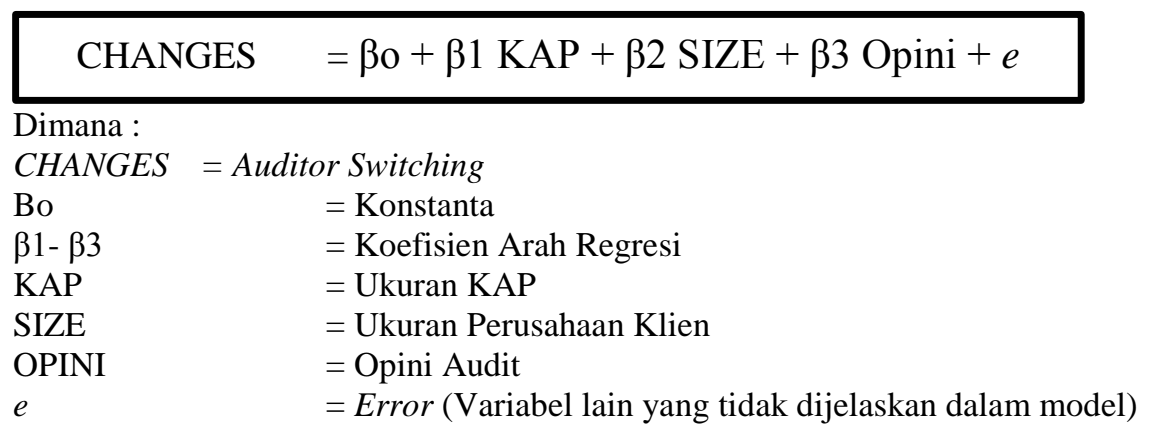

Teknik pengumpulan data untuk keperluan penelitian ini dilakukan dengan metode dokumentasi. Dokumentasi yang dilakukan adalah dengan mengumpulkan semua data sekunder (laporan keuangan perusahaan) yang isinya tentang hasil kinerja yang didaptkan perusahaan selama satu periode tertentu dan dipublikasikan di Bursa Efek Indonesia, Indonesian Capital Market Directory tentang perusahaan real estate dan properti yang terdaftar di Bursa Efek Indonesia periode 2010-2014.

\section{ISI}

\section{PENGUMPULAN DATA}

Dalam penelitian ini data yang digunakan adalah data sekunder yaitu data tentang perusahaan real estate dan properti yang terdaftar di Bursa Efek Indonesia untuk periode 2010-2014.
Sumber data tersebut berasal dari laporan keuangan perusahaan real estate dan properti yang dipublikasikan di Bursa Efek Indonesia periode 2010-2014 dan Indonesian Capital Market Directory. Penentuan sampel berdasarkan kriteriakriteria yang telah ditentukan. Berikut ini tabel 2 yang menggambarkan seleksi sampel penelitian.

Dari tabel 2 atau tabel kriteria diatas menunjukkan bahwa terdapat 49 perusahan real estate dan properti yang terdaftar di BEI periode tahun 20102014. Dari 49 perusahaan real estate dan properti yang terdaftar di BEI dari tahun 2010-2014 yang terpilih sesuai kriteria yang ada hanya terdapat 10 perusahaan yang sesuai dengan kriteria diatas, dan akan digunakan sebagai sampel penelitian dan jumlah tahun penelitian sebanyak 5 (lima) periode pengamatan sebanyak 50 pengamatan.

Tabel 2. Seleksi Sampel Penelitian

\begin{tabular}{lr}
\hline Kriteria & Jumlah \\
\hline Perusahaan real estate dan properti yang terdaftar di Bursa Efek Indonesia selama periode & 49 \\
penelitian yaitu tahun 2010 sampai dengan 2014 & \\
$\begin{array}{l}\text { Perusahaan real estate dan properti yang baru melakukan IPO periode 2010-2014. } \\
\text { Perusahaan real estate dan properti yang tidak melakukan auditor switching selama } \\
\text { periode 2010-2014. }\end{array}$ & $(26)$ \\
$\begin{array}{l}\text { Perusahaan real estate dan properti yang tidak memiliki data lengkap selama periode } \\
\text { penelitian 2010-2014. }\end{array}$ & $(1)$ \\
\hline \multicolumn{2}{c}{ Jumlah perusahaan yang memenuhi kriteria sampel } \\
\hline Jumlah tahun pengamatan & 5 \\
\hline
\end{tabular}

Sumber : Data diolah, 2016 
Tabel 3. Daftar Perusahaan Sampel

\begin{tabular}{cl}
\hline Kode & \multicolumn{1}{c}{ Nama Perusahaan } \\
\hline BAPA & Bekasi Asri Pemula Tbk \\
BIPP & Bhuawantala Indah Permai Tbk \\
COWL & Cowell Development Tbk \\
ELTY & Bakrieland Development Tbk \\
GMTD & Goa Makassar Tourism Development Tbk \\
GPRA & Perdana Gapura Prima Tbk \\
LCGP & Eureka Prima Jakarta Tbk \\
RBMS & Rista Bintang Mahkota Sejati Tbk \\
RODA & Pikko Land Development Tbk \\
SMDM & Suryamas Dutamakmur Tbk \\
\hline
\end{tabular}

Sumber: Data sekunder yang diolah dari BEI periode 2010-2014

\section{ANALISIS DATA STATISTIK DESKRIPTIF}

\section{Tabel 4. Statistik Deskriptif}

\begin{tabular}{|l|r|r|r|r|r|r|r|}
\hline & \multicolumn{1}{|c|}{$\mathrm{N}$} & \multicolumn{1}{|c|}{ Range } & Minimum & Maximum & \multicolumn{1}{c|}{ Sum } & \multicolumn{1}{c|}{ Mean } & Std. Deviation \\
\hline Ukuran_KAP & 50 & 1 & 0 & 1 & 18 & 36 & .485 \\
Ukuran_Perusahaan & 50 & 8.88 & 21.62 & 30.51 & 1347.56 & 26.9512 & 2.11339 \\
Opini_Adit & 50 & 1 & 0 & 1 & 11 & .22 & .418 \\
Auditor_Switching & 50 & 1 & 0 & 1 & 19 & .38 & .490 \\
Valid N (listwise) & 50 & & & & & & \\
\hline
\end{tabular}

Sumber: Hasil pengolahan data dengan SPSS 20.0

Hasil analisis tabel 4 dengan menggunakan statistik deskriptif terhadap auditor switching menunjukkan nilai minimum sebesar 0 , nilai maksimum sebesar 1 dengan rata-rata sebesar 0,38 dan standar deviasi 0,490. Hasil analisis dengan menggunakan statistik deskriptif terhadap ukuran KAP menunjukkan nilai minimum sebesar 0 , nilai maksimum sebesar 1 dengan rata-rata sebesar 0,36 dan standar deviasi 0,485. Hasil analisis dengan menggunakan statistik deskriptif terhadap ukuran perusahaan menunjukkan nilai minimum sebesar 21,62, nilai maksimum sebesar 30,51 dengan rata-rata sebesar 26,95 dan standar deviasi 2,113. Hasil analisis dengan menggunakan statistik deskriptif terhadap opini audit menunjukkan nilai minimum sebesar 0 , nilai maksimum sebesar 1, dengan rata-rata sebesar 0,22 dan standar deviasi 0,418 .

\section{PENGUJIAN HIPOTESIS}

Dalam uji hipotesis dengan regresi logistik cukup dengan melihat variables in the equation, pada kolom signifikan dibandingkan dengan tingkat kealpaan 0.05 (5\%). Apabila tingkat signifikansi $<0.05$, maka Ha1 Diterima. 
Tabel 5 Variable in the Equation

\begin{tabular}{|c|c|c|c|c|c|c|c|}
\hline & & $B$ & S.E. & Wald & df & Sig. & $\operatorname{Exp}(B)$ \\
\hline \multirow{4}{*}{$\begin{array}{l}\text { Step } \\
1\end{array}$} & UkuranKAP & 2.830 & .799 & 12.545 & $\overline{1}$ & .000 & 16.952 \\
\hline & UkuranPerusahaan & .171 & 203 & .705 & 1 & .401 & 1.186 \\
\hline & OpiniAudit & -1.949 & 1.259 & 2.398 & 1 & .122 & .142 \\
\hline & Constant & -6.015 & 5.677 & 1.123 & 1 & 289 & .002 \\
\hline
\end{tabular}

a. Variable(s) entered on step 1: UkuranKAP, UkuranPerusahaan, OpiniAudit

Sumber : Hasil pengolahan data Dengan SPSS 20.0

Tabel 5 di atas menunjukan hasil pengujian dengan regresi logistik pada tingkat signifikan 5\%. Dari pengujian dengan regresi logistik diatas maka diperoleh persamaan regresi logistik sebagai berikut:

CHANGES $=-6.015+2.830$ $\mathrm{KAP}+0.171 \mathrm{LnTA}-1.949$ OPINI + e

Berdasarkan hasil regresi logistik maka dapat diinterprestasikan sebagai berikut:

a. Variabel ukuran KAP menunjukkan koefisien regresi sebesar 2,830 dengan tingkat signifikansi (p) sebesar 0,000 lebih kecil dari $\alpha=$ $5 \%$. Karena tingkat signifikansi $(\mathrm{p})$ lebih kecil dari $\alpha=5 \%$ maka hipotesis pertama berhasil didukung. Maka hipotesis 1 disimpulkan bahwa $\mathrm{Ho}_{1}$ ditolak dan $\mathrm{Ha}_{1}$ diterima. Sehingga variabel ukuran KAP berpengaruh positif terhadap auditor switching.

b. Variabel LnTA menunjukkan koefisien regresi sebesar 0,171 dengan tingkat signifikansi (p) sebesar 0,401, lebih besar dari $\alpha=$ $5 \%$, maka hipotesis ke-2 tidak berhasil didukung. Penelitian ini tidak berhasil membuktikan adanya pengaruh ukuran perusahaan terhadap auditor switching, dan dapat disimpulkan bahwa hipotesis 2 atau $\mathrm{HO}_{2}$ diterima dan $\mathrm{Ha}_{2}$ ditolak.
Sehingga variabel ukuran perusahaan tidak berpengaruh terhadap auditor switching.

c. Variabel opini audit menunjukkan koefisien regresi sebesar -1,949 dengan tingkat signifikansi (p) sebesar 0,122, lebih besar dari $\alpha=$ $5 \%$. Karena tingkat signifikansi (p) lebih besar dari $\alpha=5 \%$ maka hipotesis ke-3 tidak berhasil didukung. Penelitian ini tidak berhasil membuktikan adanya pengaruh opini audit terhadap auditor switching, dan dapat disimpulkan bahwa $\mathrm{HO}_{3}$ diterima dan $\mathrm{Ha}_{3}$ ditolak. Sehingga variabel opini audit tidak berpengaruh terhadap auditor switching.

Berdasarkan hasil penelitian yang telah dilakukan dapat disimpulkan bahwa ukuran KAP memiliki pengaruh signifikan terhadap auditor switching. Hasil ini sejalan dengan penelitian Susan dan Trisnawati (2011), Wijaya (2011) yang melakukan pengujian dan sudah menemukan bukti empiris bahwa ukuran KAP berpengaruh signifikan terhadap auditor switching. Sedangkan Pratini dan Astika (2013) membuktikan bahwa ukuran KAP tidak berpengaruh terhadap auditor switching. Hasil penelitian ini menunjukkan bahwa perusahaan tidak akan melakukan pergantian KAP jika 
sudah menggunakan jasa KAP big-4. Hal ini dikarenakan KAP big-4 dianggap memiliki kualitas yang lebih baik dibandingkan dengan KAP non big-4.

Ukuran perusahaan tidak memiliki pengaruh terhadap auditor switching. Hasil penelitian ini mendukung penelitian yang dilakukan oleh Wijayanti (2010) yang menunjukkan ukuran perusahaan tidak memiliki pengaruh terhadap auditor switching. Hasil penelitian ini mengindikasikan bahwa ukuran perusahaan baik yang total asetnya besar ataupun kecil tidak menjadi pertimbangan dalam perusahaan melakukan pergantian auditor atau auditor switching.

Opini audit tidak memiliki pengaruh terhadap auditor switching. Penelitian ini mendukung penelitian yang dilakukan oleh Pratini dan Astika (2013), Juliantari dan Rasmini (2013). Namun penelitian ini tidak mendukung penelitian yang dilakukan oleh Wijaya (2011) yang menunujukkan opini audit mempunyai pengaruh terhadap audit switching. Hasil ini penelitian ini menunjukkan opini audit tidak menjadi pertimbangan perusahaan dalam melakukan pergantian auditor. Sehingga perusahaan akan tetap menggunakan KAP yang sama walaupun opini audit yang diterima pada tahun sebelumnya bukanlah opini wajar tanpa pengecualian.

\section{PENUTUP}

Berdasarkan hasil penelitian yang telah dilakukan dapat disimpulkan bahwa ukuran KAP memiliki pengaruh signifikan terhadap auditor switching. Hasil penelitian ini menunjukkan bahwa perusahaan tidak akan melakukan pergantian KAP jika sudah menggunakan jasa KAP big-4. Hal ini dikarenakan KAP big-4 dianggap memiliki kualitas yang lebih baik dibandingkan dengan KAP non big-4. Ukuran perusahaan tidak memiliki pengaruh terhadap auditor switching. Hasil penelitian ini mengindikasikan bahwa ukuran perusahaan baik yang total asetnya besar ataupun kecil tidak menjadi pertimbangan dalam perusahaan melakukan pergantian auditor atau auditor switching.

Opini audit tidak memiliki pengaruh terhadap auditor switching. Hasil ini penelitian ini menunjukkan opini audit tidak menjadi pertimbangan perusahaan dalam melakukan pergantian auditor. Sehingga perusahaan akan tetap menggunakan KAP yang sama walaupun opini audit yang diterima pada tahun sebelumnya bukanlah opini wajar tanpa pengecualian.

Untuk kesempurnaan penelitian selanjutnya, maka peneliti selanjutnya sebaiknya dapat memperluas sampel penelitian dengan mempertimbangkan penggunaan industri lain yang lebih banyak jumlah populasinya yang terdaftar di BEI sebagai populasi penelitian, dibanding dari penelitian yang hanya menggunakan dengan populasi perusahaan real estate dan properti. Dan dapat mempertimbangkan beberapa variabel independen lain, seperti financial distress, pergantian komite audit, dan sebagainya yang mungkin dapat mempengaruhi auditor switching untuk meningkatkan pengetahuan mengenai auditor switching di Indonesia. Serta dapat menggunakan alternatif proksi lain, seperti menggunakan total penjualan selain ukuran KAP, ukuran perusahaan dan opini audit. 


\section{DAFTAR PUSTAKA}

Aprillia, Ekka, 2013. Accounting Analysis Journal, Analisis FaktorFaktor yang Mempengaruhi Auditor Switching, AAJ 2.

Arens, Alvin A dan James L. Loebbecke, 2012. Auditing Pendekatan Terpadu, Terjemahan oleh Amir Abadi Yusuf, Buku Satu, Edisi Indonesia, Salemba Empat. Jakarta.

Damayanti, S. dan M. Sudarma, 2007. Simposium Nasional Vol. 11, Faktor-Faktor yang Mempengaruhi Perusahaan Berpindah Kantor Akuntan Publik.

Febrianto, R, 2009. Pergantian Auditor dan Kantor Akuntan Publik, http://rfebrianto.blogspot.com/2009 /05/pergantian-auditor-dan-kantorakuntan.

Ghozali, Imam, 2011. Aplikasi Analisis Multivariate Dengan Program SPSS, Badan Penerbit Universitas Diponegoro, Semarang.

Gujarati, Damodar, 2012. Ekonometri Dasar. Terjemahan: Sumarno Zain, Erlangga, Jakarta.

Juliantari, Ni Wayan Ari dan Ni Ketut Rasmini, 2013. Auditor Switching, Faktor-Faktor yang Mempengaruhinya. E-Jurnal Akuntansi Universitas Udayana 3.3 (2013): 231-246

Kompasiana, 2015. Kasus Kimia Farma. http://www.kompasiana.com//.

Pratini, I. G. A. Asti \& I. B. Putra Astika, 2013. Fenomena Pergantian Auditor di Bursa Efek Indonesia. EJurnal Akuntansi Universitas Udayana 5.2 2013: 470-482.

Purwono, Edi, 2011. Aspek-Aspek ADP, Audit Pengendalian Intern Pada Komputerisasi, Andi, Yogyakarta.

Sukrisno, Agoes, 2012. Auditing (Pemeriksaan Akuntan) oleh
Kantor Akuntan Publik. Edisi Ketiga. Penerbit Fakultas Ekonomi Universitas Trisakti, Jakarta.

Sinarwati, 2010. Mengapa Perusahaan Manufaktur Yang Terdafar Di BEI Melakukan Pergantian Kantor Akuntan Publik, Simposium Nasional Akuntansi (SNA) XIII Purwokerto.

Sugiyono, 2012. Metode Penelitian pendidikan pendekatan kuantitatif, kualitatif, dan R\&D: ALFABETA, Bandung.

Susan dan Trisnawati, Estralita, 2011. Faktor-faktor yang mempengaruhi perusahaan melakukan Auditor Switch, Jurnal Bisnis dan Akuntansi, vol. 13 No. 2. Agustus 2011, 131-144.

Suwito, Edi dan Arleen Herawaty, 2005. Analisis Pengaruh Karakteristik Perusahaan Terhadap Tindakan Perataan Laba yang Dilakukan Oleh Perusahaan yang Terdaftar di Bursa Efek Jakarta".SNA.Vol.VIII Solo, 15-16 September.

Wibowo, Arie dan Rossieta, Hilda, 2009.

Faktor-Faktor Determinasi

Kualitas Audit-Suatu Studi dengan Pendekatan Earning Surprise Benchmark".Simposium nasional Akuntansi XII, Palembang, hal. 134.

Wijaya, R.M Aloysius Pangky, 2011. Faktor-Faktor Yang Mempengaruhi Pergantian Auditor Oleh Klien, Jurnal Fakultas Ekonomi dan Bisnis Universitas Brawijaya, Malang.

Wijayanti, Martina Putri, 2010, Faktorfaktor yang Mempengaruhi Auditor Switching di Indonesia. Fakultas Ekonomi Universitas Diponegoro, Semarang. 